\section{Weed Management in Transplanted Bell Pepper (Capsicum annuum) with Pretransplant Tank Mixes of Sulfentrazone, S-metolachlor, and Dimethenamid-p}

\author{
Darren E. Robinson, Kristen McNaughton, and Nader Soltani ${ }^{1}$ \\ Department of Plant Agriculture, University of Guelph, Ridgetown Campus, \\ 120 Main Street East, Ridgetown, Ontario, Canada NOP 2 CO
}

Additional index words. Capsicum annuum, dimethenamid-p, pretransplant herbicides, pepper injury, s-metolachlor, sulfentrazone, yield

\begin{abstract}
Pepper growers currently have limited access to many effective broadleaf herbicides. Field trials were conducted over a 3-year period in Ontario to study the effect of tank mixtures of sulfentrazone (100 or $200 \mathrm{~g} \cdot \mathrm{ha}^{-1}$ a.i.) with either s-metolachlor (1200 or $2400 \mathrm{~g} \cdot \mathrm{ha}^{-1}$ a.i.) or dimethenamid-p $\left(750\right.$ or $1500 \mathrm{~g} \cdot \mathrm{ha}^{-1}$ a.i.) on transplanted bell pepper. Under weed-free conditions, there was no visual injury or reduction in plant height, fruit number, fruit size, or marketable yield of transplanted pepper with pretransplant applications of sulfentrazone applied in tank mixtures with s-metolachlor or dimethenamid-p. The tank mixture of sulfentrazone $+s$-metolachlor gave greater than $\mathbf{8 5} \%$ control of redroot pigweed (Amaranthus retroflexus) and eastern black nightshade (Solanum ptycanthum), but only $70 \%$ to $76 \%$ control of velvetleaf (Abutilon theophrasti), common ragweed (Ambrosia artemisiifolia), and common lambsquarters (Chenopodium album). The combination of sulfentrazone + dimethenamid-p provided good to excellent control of all weed species except velvetleaf. Based on this study, sulfentrazone and dimethenamid-p have potential for minor use registration in pepper.
\end{abstract}

Pepper is grown on $\approx 1200$ ha with farm gate receipts close to $\$ 12$ million in 2005 in Ontario (Mailvaganam, 2006). Bell pepper is not a competitive crop and yield reductions can result in significant financial loss if weeds are not properly controlled (Eshel et al., 1973; Frank et al., 1992); therefore, broadleaf weed control is one of the most important weed management considerations in pepper production. Current problem weeds include velvetleaf (Abutilon theophrasti Medic.), redroot pigweed (Amaranthus retroflexus L.), common ragweed (Ambrosia artemisiifolia L.), common lambsquarters (Chenopodium album L.), and eastern black nightshade (Solanum ptycanthum Dun.).

Napropamide, trifluralin, chlorthal dimethyl, and s-metolachlor are the currently registered soil-applied herbicides for pepper production in Ontario [Ontario Ministry of Agriculture, Food and Rural Affairs (OMAFRA), 2006a]. Although napropamide

\footnotetext{
Received for publication 6 Mar. 2008. Accepted for publication 2 Apr. 2008.

Funding for this project was provided by the Ontario Processing Vegetable Growers and The Pest Management Centre of Agriculture and AgriFood Canada, Pesticide Risk Reduction and Minor Use Research programs.

We acknowledge Dave Bilyea for his expertise and technical assistance in these studies.

${ }^{1}$ To whom reprint requests should be addressed; e-mail nsoltani@ridgetownc.uoguelph.ca
}

can provide good control of redroot pigweed and common lambsquarters early in the season, it does not provide long-term residual control of these weeds. Additionally, it is weak on common ragweed, velvetleaf, and eastern black nightshade. Trifluralin is used primarily as a grass herbicide, although it will provide early-season control of redroot pigweed and common lambsquarters. Chlorthal dimethyl will give good control of common lambsquarters and suppresses redroot pigweed, but it provides poor control of velvetleaf, common ragweed, and eastern black nightshade. S-metolachlor controls redroot pigweed and eastern black nightshade and was recently registered for use in pepper in Ontario. S-metolachlor, because of availability, grower experience, and cost, is the primary pretransplant graminicide used for weed control in pepper in Ontario. As a result, s-metolachlor was used as the tank mixture partner with sulfentrazone in these trials. Finally, dimethenamid-p was included to compare an alternate graminicide, which offers some control of common ragweed, redroot pigweed, and eastern black nightshade. Dimethenamid-p is not currently registered in pepper but could be an effective option to control troublesome weeds for pepper growers in Ontario. It would also be of significant benefit to growers in Ontario to have a tank mix to control weed species that s-metolachlor is weak on, specifically velvetleaf, common ragweed, and common lambsquarters.
The first objective of this research was to identify pretransplant herbicides with activity on velvetleaf, common ragweed, and common lambsquarters with an acceptable level of tolerance in pepper. The second objective of this research was to determine weed control and tolerance of these pretransplant herbicides applied as a tank mixture.

\section{Materials and Methods}

Field studies were conducted at the University of Guelph Ridgetown Campus, Ridgetown, Ontario, from 2003 to 2005. The soil was a Normandale fine sandy loam with $53.9 \%$ sand, $29.3 \%$ silt, $16.7 \%$ clay, $4.7 \%$ organic matter, and $\mathrm{pH}$ of 7.5 in 2003 ; a Brookston clay loam with $29.4 \%$ sand, $36.2 \%$ silt, $34.5 \%$ clay, $5.8 \%$ organic matter, and $\mathrm{pH}$ of 5.8 in 2004; and a Normandale very fine sandy loam with $80.6 \%$ sand, $12.3 \%$ silt, $7.2 \%$ clay, $6.1 \%$ organic matter, and $\mathrm{pH}$ of 7.2 in 2005 . Each trial area was mouldboard plowed in the fall and cultivated twice with a field S-tine cultivator and rolling basket harrows in the spring before transplanting.

The experimental design was a randomized complete block split-plot design with four replications. The main plot treatments were s-metolachlor (1200 and $2400 \mathrm{~g} \cdot \mathrm{ha}^{-1}$ a.i.), dimethenamid-p (750 and $1500 \mathrm{~g} \cdot \mathrm{ha}^{-1}$ a.i.), sulfentrazone (100 and $200 \mathrm{~g} \cdot \mathrm{ha}^{-1}$ a.i.), s-metolachlor + sulfentrazone $(1200+100$ and $2400+200 \mathrm{~g} \cdot \mathrm{ha}^{-1}$ a.i.), and dimethenamid-p + sulfentrazone $(750+100$ and $1500+$ $200 \mathrm{~g} \cdot \mathrm{ha}^{-1}$ a.i.). An untreated control was included for comparison. Treatments were applied $1 \mathrm{~d}$ before transplanting using a $\mathrm{CO}_{2}$ pressurized backpack sprayer calibrated to deliver $200 \mathrm{~L} \cdot \mathrm{ha}^{-1}$ at $207 \mathrm{kPa}$ using 8002 flat-fan nozzles (Spraying Systems Co., Wheaton, IL). The boom was $1.0 \mathrm{~m}$ long with three nozzles spaced $50 \mathrm{~cm}$ apart.

Plots were $1.5 \mathrm{~m}$ wide by $8 \mathrm{~m}$ long. 'Enterprise' pepper transplants, $\approx 6$ to $8 \mathrm{~cm}$ tall at transplanting, were planted at a depth of $5 \mathrm{~cm}$ in twin rows (30 cm apart) at a rate of 29,000 transplants/ha on 29 May 2003, 7 June 2004, and 1 June 2005. There was no need for irrigation in these studies because rainfall provided adequate moisture. Plots were fertilized according to recommended Ontario crop production practices (OMAFRA, 2006b). Annual grass weeds were removed from the entire trial with an application of sethoxydim ( $150 \mathrm{~g} \cdot \mathrm{ha}^{-1}$ a.i. $)$ plus a surfactant/ solvent $\left(1 \mathrm{~L} \cdot \mathrm{ha}^{-1}\right)$ when the grasses reached the three to four leaf stage or pulled by hand if necessary.

The subplot factor was weed-free or weedy; one half of each plot (including the untreated control) was kept weed-free by hoeing on a weekly basis from transplanting until harvest, whereas the other half of each plot was left weedy.

Visual crop injury was rated on the weedfree half of each plot 7, 14, and $28 \mathrm{~d}$ after transplanting (DAT) using a scale of $0 \%$ to $100 \%$. A rating of 0 was defined as no visible plant injury, and a rating of 100 was defined as total plant necrosis. At 56 DAT, broadleaf 
weed counts were recorded in two $0.5-\mathrm{m}^{2}$ quadrats placed in the middle of the weedy half of each plot. Weed density was taken as the average of these two readings and extrapolated to $1 \mathrm{~m}^{2}$. Peppers were hand-harvested at crop maturity from the middle $3 \mathrm{~m}$ of the weedy and the weed-free halves of each plot at all locations and separated into marketable and nonmarketable fruit. Fruit number, fruit size, and yield were determined. Fruits were harvested on 28 Aug. and 11 Sept. 11 2003, on 20 and 31 Aug. in 2004, and on 17 and 24 Aug. in 2005.

Data were subjected to analysis of variance to determine the effect of year and yearby-treatment interactions on visual injury, broadleaf weed control, marketable fruit number, marketable fruit size, and marketable yield. Because the year-by-treatment interactions were not significant, data were combined over years and analyzed using the PROC MIXED procedure of Statistical Analysis Systems (1999). Variances were partitioned into random effects of years, blocks within years, and their interactions with fixed treatment effects. Significance of random effects was tested using a Z-test of the variance estimate and fixed effects were tested using F-tests. Error assumptions of the variance analyses (random, homogeneous, normal distribution of error) were confirmed using residual plots and the Shapiro-Wilk normality test. Percent visual injury at 7 , 14 , and 28 DAT was subjected to $\log$ transformation, whereas percent weed control for each weed species at 56 DAT was subjected to arcsine transformation (Bartlett, 1947), compared on the transformed scale, and converted back to the original scale for presentation of results (Bartlett, 1947). Treatment means for visual injury, broadleaf weed control, marketable fruit number, marketable fruit size, and marketable yield were separated using Fisher's protected least significant differences $(\alpha=0.05)$.

\section{Results and Discussion}

Pepper tolerance to pretransplant herbicides. Visual injury was less than $4 \%$ in all the treatments tested, including the tank mix combinations of s-metolachlor + sulfentrazone or dimethenamid-p + sulfentrazone (Table 1). The authors are unaware of any studies that have examined pepper tolerance to dimethenamid-p. Grey et al. (2002) observed significant visual injury, including stunting, chlorosis, and necrosis as well as significant reductions in plant stand and yield in pepper with sulfentrazone at a rate of 420 $\mathrm{g} \cdot \mathrm{ha}^{-1}$ a.i. At the rates tested in the current study, pepper exhibited excellent tolerance to sulfentrazone. In addition to a lack of visual injury, fruit number per $3 \mathrm{~m}$ of row, mean fruit size, and marketable yield were not less than the untreated, weed-free control in any of the treatments (Table 2). It is concluded that transplanted pepper has excellent tolerance to pretranplant applications of dimethenamid-p (750 and $1500 \mathrm{~g} \cdot \mathrm{ha}^{-1}$ a.i.), sulfentrazone (100 and $200 \mathrm{~g} \cdot \mathrm{ha}^{-1}$ a.i.) as well as tank mixes of dimethenamid-p or s-metolachlor plus sulfentrazone.

Weed control in pepper with pretransplant herbicides. S-metolachlor alone (1200 g.ha $\mathrm{h}^{-1}$ a.i.) provided greater than $81 \%$ control of redroot pigweed, $75 \%$ control of eastern black nightshade, but less than $50 \%$ control of velvetleaf, common ragweed, and common lambsquarters (Table 3 ). Dimethenamid-p alone (750 g.ha ${ }^{-1}$ a.i.) provided better than $80 \%$ control of redroot pigweed and eastern black nightshade; however, control of velvetleaf, common ragweed, and common lambsquarters was less than $70 \%$ (Table 3). The pretransplant application of

sulfentrazone provided $80 \%$ control of common lambsquarters, $64 \%$ and $70 \%$ control of velvetleaf and redroot pigweed, but less than $60 \%$ control of common ragweed and eastern black nightshade (Table 3 ). At the rates used in this study, s-metolachlor, dimethenamid-p, and sulfentrazone each applied on their own did not provide commercially acceptable control (i.e., greater than $80 \%$ ) of the major broadleaf weed species typically found in pepper fields in southwestern Ontario. The poor control provided by each of these herbicides when applied alone corresponded with significant reductions in fruit number per $3 \mathrm{~m}$ of row, mean fruit size, and marketable yield (Table 4).

Table 1 . Mean percent injury 7, 14, and $28 \mathrm{~d}$ after transplanting (DAT) peppers for each herbicide treatment in weed-free subplots from 2003 to 2005 at Ridgetown, Ontario ${ }^{z}$.

\begin{tabular}{lcccc}
\hline Herbicide a.i.(s) & $\begin{array}{c}\text { Herbicide rate(s) } \\
\left(\mathrm{g} \cdot \mathrm{ha}^{-1} \mathrm{a} . \mathrm{i} .\right)\end{array}$ & 7 DAT (\%) & 14 DAT (\%) & 28 DAT (\%) \\
\hline S-metolachlor & 1200 & $0 \mathrm{a}$ & $0 \mathrm{a}$ & $0 \mathrm{a}$ \\
S-metolachlor & 2400 & $0 \mathrm{a}$ & $1 \mathrm{a}$ & $1 \mathrm{a}$ \\
Dimethenamid-p & 750 & $1 \mathrm{a}$ & $0 \mathrm{a}$ & $0 \mathrm{a}$ \\
Dimethenamid-p & 1500 & $0 \mathrm{a}$ & $1 \mathrm{a}$ & $0 \mathrm{a}$ \\
Sulfentrazone & 100 & $0 \mathrm{a}$ & $0 \mathrm{a}$ & $0 \mathrm{a}$ \\
Sulfentrazone & 200 & $1 \mathrm{a}$ & $0 \mathrm{a}$ & $1 \mathrm{a}$ \\
S-metolachlor + sulfentrazone & $1200+100$ & $0 \mathrm{a}$ & $0 \mathrm{a}$ & $2 \mathrm{a}$ \\
S-metolachlor + sulfentrazone & $2400+200$ & $0 \mathrm{a}$ & $2 \mathrm{a}$ & $2 \mathrm{a}$ \\
Dimethenamid-p + sulfentrazone & $750+100$ & $1 \mathrm{a}$ & $1 \mathrm{a}$ & $2 \mathrm{a}$ \\
Dimethenamid-p + sulfentrazone & $1500+200$ & $2 \mathrm{a}$ & $2 \mathrm{a}$ & 2 \\
LSD & & 1 & 2 & \\
\hline
\end{tabular}

${ }^{\mathrm{z}}$ Means followed by the same letter within a column are not significantly different according to a Fisher's protected least significant difference (LSD) test $(P<0.05)$.

Table 2. Marketable fruit number per $3 \mathrm{~m}$ of row, fruit size, and yield of pepper for each herbicide treatment in weed-free subplots from 2003 to 2005 at Ridgetown, Ontario ${ }^{z}$.

\begin{tabular}{|c|c|c|c|c|}
\hline Herbicide a.i. & $\begin{array}{l}\text { Herbicide rate } \\
\left(\mathrm{g} \cdot \mathrm{ha}^{-1} \text { a.i. }\right)\end{array}$ & $\begin{array}{l}\text { Fruit number } \\
\left(3 \mathrm{~m} \text { of } \text { row }^{-1}\right)\end{array}$ & Fruit size $(\mathrm{g})$ & Yield $\left(\mathrm{t} \cdot \mathrm{ha}^{-1}\right)$ \\
\hline Untreated weed-free control & & $27 \mathrm{a}$ & $152 \mathrm{a}$ & $9.1 \mathrm{a}$ \\
\hline S-metolachlor & 1200 & $28 \mathrm{a}$ & $156 \mathrm{a}$ & $9.7 \mathrm{a}$ \\
\hline S-metolachlor & 2400 & $28 \mathrm{a}$ & $151 \mathrm{a}$ & $9.4 \mathrm{a}$ \\
\hline Dimethenamid-p & 750 & $31 \mathrm{a}$ & $153 \mathrm{a}$ & $10.5 \mathrm{a}$ \\
\hline Dimethenamid-p & 1500 & $30 \mathrm{a}$ & $150 \mathrm{a}$ & $10.0 \mathrm{a}$ \\
\hline Sulfentrazone & 100 & $27 \mathrm{a}$ & $158 \mathrm{a}$ & $9.5 \mathrm{a}$ \\
\hline Sulfentrazone & 200 & $30 \mathrm{a}$ & $153 \mathrm{a}$ & $10.2 \mathrm{a}$ \\
\hline S-metolachlor + sulfentrazone & $200+100$ & $28 \mathrm{a}$ & $158 \mathrm{a}$ & $9.8 \mathrm{a}$ \\
\hline S-metolachlor + sulfentrazone & $2400+200$ & $28 \mathrm{a}$ & $159 \mathrm{a}$ & $9.9 \mathrm{a}$ \\
\hline Dimethenamid-p + sulfentrazone & $750+100$ & $29 \mathrm{a}$ & $150 \mathrm{a}$ & $9.7 \mathrm{a}$ \\
\hline Dimethenamid-p + sulfentrazone & $1500+200$ & $29 \mathrm{a}$ & $162 \mathrm{a}$ & $10.4 \mathrm{a}$ \\
\hline LSD & & 5 & 16 & 1.8 \\
\hline
\end{tabular}

${ }^{z}$ Means followed by the same letter within a column are not significantly different according to a Fisher's protected least significant difference (LSD) test $(P<0.05)$.

Table 3. Percent control of Abutilon theophrasti (ABUTH), Amaranthus retroflexus (AMARE), Ambrosia artemisiifolia (AMBEL), Chenopodium album (CHEAL), and Solanum ptycanthum (SOLPT) at $56 \mathrm{~d}$ after transplanting pepper in weedy subplots from 2003 to 2005 at Ridgetown, Ontarioz.

\begin{tabular}{|c|c|c|c|c|c|c|}
\hline \multirow[b]{2}{*}{ Herbicide a.i. } & \multirow{2}{*}{$\begin{array}{l}\text { Herbicide rate } \\
\left(\mathrm{g} \cdot \mathrm{ha}^{-1} \text { a.i. }\right)\end{array}$} & \multicolumn{5}{|c|}{ Weed control $(\%)$} \\
\hline & & ABUTH & AMARE & AMBEL & CHEAL & SOLPT \\
\hline S-metolachlor & 1200 & $42 \mathrm{~b}$ & $81 \mathrm{~b}$ & $44 \mathrm{~b}$ & $47 \mathrm{~b}$ & $75 \mathrm{a}$ \\
\hline Dimethenamid-p & 750 & $42 \mathrm{~b}$ & $80 \mathrm{~b}$ & $62 \mathrm{ab}$ & $56 \mathrm{ab}$ & $82 \mathrm{a}$ \\
\hline Sulfentrazone & 100 & $64 a$ & $70 \mathrm{c}$ & $45 \mathrm{~b}$ & $80 \mathrm{a}$ & $57 \mathrm{~b}$ \\
\hline $\begin{array}{l}\text { S-metolachlor + } \\
\text { sulfentrazone }\end{array}$ & $1200+100$ & $70 \mathrm{a}$ & $93 \mathrm{a}$ & $70 \mathrm{ab}$ & $76 \mathrm{ab}$ & $89 \mathrm{a}$ \\
\hline $\begin{array}{l}\text { Dimethenamid-p }+ \\
\text { sulfentrazone }\end{array}$ & $750+100$ & $66 \mathrm{a}$ & 93 a & $83 \mathrm{a}$ & $88 \mathrm{a}$ & $90 \mathrm{a}$ \\
\hline LSD & & 8 & 4 & 18 & 13 & 7 \\
\hline
\end{tabular}

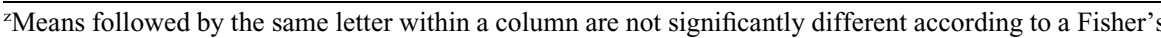
protected least significant difference (LSD) test $(P<0.05)$. 
Table 4. Marketable fruit number per $3 \mathrm{~m}$ of row, fruit size, and yield of pepper for each herbicide treatment in weedy subplots from 2003 to 2005 at Ridgetown, Ontario (comparable values in the untreated, weed-free control are also shown) ${ }^{\mathrm{z}}$.

\begin{tabular}{|c|c|c|c|c|}
\hline Herbicide a.i. & $\begin{array}{l}\text { Herbicide rate } \\
\left(\mathrm{g} \cdot \mathrm{ha}^{-1} \text { a.i. }\right)\end{array}$ & $\begin{array}{l}\text { Fruit number } \\
\left(3 \mathrm{~m}^{\circ} \text { row }^{-1}\right)\end{array}$ & $\begin{array}{c}\text { Fruit } \\
\text { size }(\mathrm{g})\end{array}$ & $\begin{array}{c}\text { Yield } \\
\left(\mathrm{t} \cdot \mathrm{ha}^{-1}\right)\end{array}$ \\
\hline Untreated, weedy control & & $4 \mathrm{c}$ & $39 \mathrm{c}$ & $0.3 \mathrm{c}$ \\
\hline S-metolachlor & 1200 & $14 \mathrm{~b}$ & $109 \mathrm{~b}$ & $3.3 \mathrm{~b}$ \\
\hline Dimethenamid-p & 750 & $17 \mathrm{~b}$ & $107 \mathrm{~b}$ & $4.0 \mathrm{~b}$ \\
\hline Sulfentrazone & 100 & $16 \mathrm{~b}$ & $101 \mathrm{~b}$ & $3.6 \mathrm{~b}$ \\
\hline S-metolachlor + sulfentrazone & $1200+100$ & $25 \mathrm{a}$ & $157 \mathrm{a}$ & $8.7 \mathrm{a}$ \\
\hline Dimethenamid-p + sulfentrazone & $750+100$ & $26 \mathrm{a}$ & $150 \mathrm{a}$ & $8.7 \mathrm{a}$ \\
\hline Untreated, weed-free control & & $27 \mathrm{a}$ & $152 \mathrm{a}$ & $9.1 \mathrm{a}$ \\
\hline LSD & & 4 & 34 & 2.7 \\
\hline
\end{tabular}

${ }^{\mathrm{z}}$ Means followed by the same letter within a column are not significantly different according to a Fisher's protected least significant difference (LSD) test $(P<0.05)$.

The tank mix combination of s-metolachlor + sulfentrazone $\left(1200+100 \mathrm{~g} \cdot \mathrm{ha}^{-1}\right.$ a.i. $)$ provided greater than $80 \%$ control of common ragweed, redroot pigweed, common lambsquarters, and eastern black nightshade and $70 \%$ control of velvetleaf (Table 3 ). The dimethenamid- $p+$ sulfentrazone $(750+100$ g.ha ${ }^{-1}$ a.i.) treatment provided similar control of the major broadleaf weed species as the smetolachlor + sulfentrazone treatment (Table $3)$. Velvetleaf control was not commercially acceptable in any of the treatments tested; however, research is currently underway to register clomazone in transplanted peppers, which would provide growers with an excellent tool to control this weed. The level of control provided by the tank mix combina- mid-p at rates evaluated can be useful herbicide options for weed management in pepper.

\section{Literature Cited}

Bartlett, M.S. 1947. The use of transformations. Biometrics 3:39-52.

Eshel, Y., J. Katan, and D. Palevitch. 1973. Selective action of diphenamid and napropamide in pepper and weeds. Weed Res. 13:379384.

Frank, J.R., P.H. Schartwz Jr and W.E. Potts. 1992. Modelling the effects of weed interference periods and insects on bell peppers. Weed Sci. 40:308-312.

Grey, T.L., D.C. Bridges, and D.C. NeSmith. 2002. Transplanted pepper (Capsicum anuum) tolerance to selected herbicides and method of application. Journal of Vegetable Crop Production 8:27-39.

Mailvaganam, S. 2006. Farm value and harvested area of vegetable crops, Ontario, 1980-2005. 25 May 2007. <http://www.omafra.gov.on.ca/ english/stats/hort/value_veg.html\#3>.

Ontario Ministry of Agriculture. Food and Rural Affairs (OMAFRA). 2006a. Guide to weed control 2006-2007. Publication 75. Ontario Ministry of Agriculture, Food and Rural Affairs, Toronto, Ontario. p. 243-244.

Ontario Ministry of Agriculture. Food and Rural Affairs (OMAFRA). 2006b. Vegetable production recommendations 2006-2007. Publication 363. Ontario Ministry of Agriculture, Food and Rural Affairs, Toronto, Ontario. p. 144-145.

Statistical Analysis Systems (SAS). 1999. The SAS system for windows, Release 8.0. Statistical Analysis Systems Institute, Cary, NC. 